\title{
ISSUANCE OF GREEN BOND FOR SUSTAINABLE DEVELOPMENT OF PEATLANDS
}

\author{
${ }^{1}$ Naradipatya Pratanjana, ${ }^{2}$ Gumanti O. Simbolon \\ 1,2 PT Sarana Multigriya Finansial (Persero), Jakarta, Indonesia \\ I'pratanjana@gmail.com,22gumantios@gmail.com
}

\begin{abstract}
Peatlands, with their important role, are in need of great attention, both from the government and also environmentalists. The role of corporations is really needed and is expected to be able to accelerate the improvement of the quality of peatlands so that the benefits are maintained. Issuance of Green Bond is expected to be able to encourage the achievement of this goal. It is hoped that companies operating in and around the Peatland area will be able to create sustainable Peatland development efforts. The synergy between companies and green investors is expected to be an aspect of improving the economy, both for companies, investors, and the public. Companies as publishers have an increasingly large role in maintaining the balance of peatlands. Benefits in the form of incentives from the Financial Services Authority (OJK) will also be obtained by companies that issue green bonds. Investors, especially green investors who are interested in environmental issues, will have new investment alternatives. The emergence of a development program initiated by the Company, of course, will also have an impact on society, in the form of the withdrawal of a number of workers, as well as the increase in other economic activities as a result of the increase in the standard of living of the community.
\end{abstract}

Keywords: Green Bond, Peatland

DOI: $10.33541 /$ sp.v21i3.2259

Sociae Polites : Majalah IImiah Sosial Politik

Faculty of Social and Political Science, Universitas Kristen Indonesia

ISSN 1410-3745 print/ ISSN 2620-4975 online

Volume 21, Number 2 (Youth Peatland Conference)

Pages 179-195 


\section{Introduction}

\subsection{Background}

Peatlands, which are rich in organic matter, are one of the concerns of the Indonesian government at this time. Apart from having good benefits, the number of peatlands in Indonesia is also fairly large. In fact, Indonesia is the largest contributor to peatlands in Southeast Asia. Indonesia has the largest peatlands among tropical countries, which is around 21 million ha, or $10.8 \%$ of Indonesia's land area. Most of the peat swamp areas are in four major islands, namely in Sumatra 35\%, Kalimantan 32\%, Papua 30\%, and a small part are in Sulawesi, Halmahera and Seram 3\% (Radjagukguk, 1992; 1995). According to Government Regulation Number 71 of 2014 concerning the Protection and Management of Peat Ecosystems, peat is organic material that is formed naturally from imperfectly decomposed plant debris and accumulates in swamps.

In recent years the use of peatlands is so large that the area of peatland distribution in Indonesia has decreased significantly. One of the factors driving the reduction of peatlands in Indonesia is the conversion of peatlands to agricultural land. "The conversion of peatlands to agricultural land is inevitable in an effort to increase agricultural production in Indonesia" (Sola, Hardi 2005). The conversion of peatland functions will certainly affect the balance of the ecosystem and its functions. The absorption capacity of peatlands for carbon and water is, of course, disturbed and imbalanced. Therefore, effective and efficient management is needed in order to preserve the distribution of peatlands.

The government's attention to peatland management is manifested through the formation of an independent institution, namely the Peat Restoration Agency (BRG). Nevertheless, peatland management will certainly run better if every party involved in the peatland area takes part in the implementation process. Of course, companies operating in peatland distribution areas can also play a major role in the achievement of peatland management. Oil palm plantations are one of the many business sectors that operate in areas of peatland distribution. According to data from the Central Statistics Agency (2018), the five largest palm oil producers in Indonesia are in the area of distribution of peatlands, including North Sumatra, Riau, South Sumatra, West Kalimantan and Central Kalimantan.

From 2013 to 2018, oil palm plantations in Indonesia tended to increase, except in 2016 , it experienced a decline. The increase ranged from $2.77 \%$ to $10.55 \%$ per year, while in 2016 , there was a decrease of $0.52 \%$. In 2014 , Indonesia's oil palm plantation area was recorded at 10.75 hectares, increasing to 11.26 million hectares in 2015 (an increase of $4.70 \%$ ). In 2016, the total area of oil palm plantations decreased by $0.52 \%$ from 2015 to 11.20 million ha. Furthermore, in 2017 the oil palm plantation area has increased by $10.55 \%$, and in 2018 it is predicted to be 12.76 million ha (Central Statistics Agency, 2018). 
Figure 1. Development of Indonesian Palm Oil Plantation Area and Production 2014-2018 (2018)

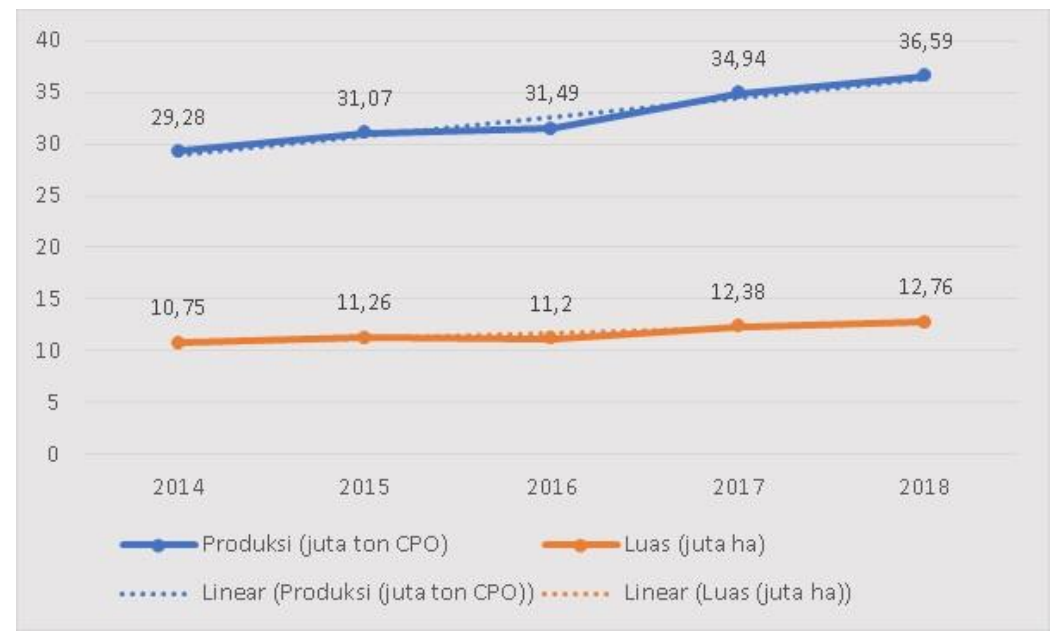

(Source: Central Bureau of Statistics)

Apart from the change in the function of peatlands, one of the factors that have influenced peatlands is the occurrence of land fires. Like what happened in Kalimantan in 2015 , forest fires occurred, which caused around 18,665 ha or $13 \%$ of the total area of 148,194 ha of peatland. Peatland fires will certainly have a negative and significant impact on the balance of the earth's ecosystem. The high absorption capacity of peatlands to carbon is one of the driving factors for global warming when the peatlands experience fire and/or damage. Therefore, it requires good management of the existence of peatlands, including initiatives from companies operating in peatland distribution areas.

Implementing business activities and managing peatlands certainly requires a good management and cost management system so that both aspects can be achieved. Currently, the Company has an environmentally based funding alternative, namely the Green Bond. In general, Green Bond can be defined as debt securities whose issuance proceeds are used for environmentally friendly methods and projects. (Financial Services Authority, 2016. With the Green Bond instrument, it is hoped that it can help companies, including oil palm companies operating in peatland areas, to increase environmental-based projects along with integrated peatland management with the project.

\section{Literature Review}

\subsection{Peatlands}

Peat as a wetland ecosystem is a soil structure that contains lots of organic matter as a result of a long-term decomposition process. The process of forming peatlands is not always the same for every region. Therefore peatlands have different characteristics in each region. The characteristics of the peat ecosystem consist of characteristics that include physical and chemical characteristics.

\subsubsection{Physical Properties of Peat Soil}

\subsubsection{Peat Maturity}

Maturity refers to the level of weathering of the materials found in peatlands. This level of practice will be one of the driving factors for peatland productivity, fertility, and 
nutrient availability. Peatlands with a good level of weathering will be a major factor for use as agricultural land because they provide a better fertility rate than peatlands with a low level of weathering. Based on the level of maturity, peatlands are divided into three parts, namely capric (ripe), hemic (half-ripe), and fabric (raw).

\subsubsection{Water content}

When compared to mineral soils, peatlands have the ability to absorb and store water better. The structure of peat soil gives rise to the ability of peatlands to absorb 1-13 times their weight in the form of standing water.

\subsubsection{Bulk Density}

Shows the mass of the solid mass in a given volume. Soils with low bulk density generally have high porosity, so the ability to absorb and channel water is also high. But on the other hand, if the peatlands have too low bulk density, then the land's ability to withstand the load (bearing capacity) is low.

\subsubsection{Subsidence}

Subsidence or land subsidence is a situation that often occurs on peatlands due to drainage measures. The drainage process causes the water between the peat masses to flow out, causing the peat to shrink.

\subsubsection{Load-bearing power}

The ability to withstand loads is classified as low, making it difficult for peatlands to be used for crop production. This character can be observed by the number of plants that grow erect in peatland areas. However, if peatlands have a high level of maturity, they will become denser and have a better load-bearing capacity when compared to peatlands with low maturity levels.

\subsubsection{Irreversible Drying}

Peat with a water content of less than $100 \%$ of the weight, in general, has undergone irreversible drying. The dry land no longer has a good absorption ability of water and nutrients and thus will be more flammable. The dry soil is often seen on the surface of peatlands and floating in puddles, shaped like sand, so it is often called pseudo sand.

\subsubsection{Chemical Properties of Peat Soil}

\subsubsection{Soil Acidity}

The roughness of peat soil will usually be higher as the thickness of the soil increases. In general, peatlands with low maturity levels have higher acid levels.

\subsubsection{Cation Exchange Capacity}

Peatlands have a high level of cation-exchange capacity due to the negative charge that depends on the $\mathrm{pH}$ originating from carboxylate and phenolic groups. The high CEC 
causes the soil's response to acid-base reactions in the soil solution to reach equilibrium, requiring more reactants (ameliorants).

\subsubsection{Levels of Organic Acids}

In Indonesia, the lignin content of peatlands is higher than peatlands in areas with subtropical climates. The decomposition of lignin produces phenolic acid, while cellulose and hemicellulose become carboxylates. Almost all chemical processes in peatlands are caused by these organic acids and take place in the reactive sites of functional groups, especially $\mathrm{COOH}$, -OH-phenol, and -OH-alcohol.

\subsubsection{Availability of Macro Nutrients}

Peatlands generally have low availability of Nitrogen, Phosphorus, Potassium, Calcium, and Magnesium. Most of the Nitrogen, Phosphorus, and Potassium found in peatlands are in organic form.

\subsubsection{Availability of Micro Nutrients}

Apart from macronutrients, peatlands also contain micronutrients such as copper, zinc, iron, manganese, boron, and molybdenum.

\subsubsection{Ash content}

The ash content in peatlands is an indicator to see the level of soil fertility. In general, peatlands that have never experienced lightning and fire have an ash content of less than $1 \%$.

2.2 Functions and Benefits of Peatlands

\subsubsection{Ecological Function}

a. Protects spring water, maintains groundwater balance, and functions in extreme conditions such as long-term drought and heavy rainfall

b. Maintain soil moisture

c. Storing nutrients to increase soil productivity

d. Store and recycle nutrients

e. Decompose pollutants

f. They are helping to maintain climate stability, especially helping to absorb some carbon in the earth, which is vulnerable to creating global marketing.

2.2.2 Biological Functions

a. To become a place to live for food, both plants, and animals, which are a source of food for humans

b. As a source of medicine, from plants that can increase antibiotics and are used as ingredients for making medicine

\subsubsection{Socio-Economic Functions}

a. Become a place for the development of education and research. Peatlands can be used as a living laboratory for various studies 
b. Can be managed into recreational and tourism facilities, which can add a positive impact to the community

c. Peat areas can be used to support plant cultivation

d. Can encourage community economic growth through the development of swamp fish farming

\subsection{Green Bonds}

Green bonds are a relatively new type of investment product. Green bonds are also alternative financing for projects that have a positive impact on the environment. The International Capital Market Association (ICMA) defines green bonds as follows:

"A green bond is differentiated from a regular bond by its label, which signifies a commitment to exclusively use the fund raised to finance or refinance" green projects, assets or business activities. "

Another definition of green bonds is bonds designed to promote sustainability and support climate-related or other environmental projects (Jhon Chiang, 2017). Based on Article 1, point 2 of the Financial Services Authority Regulation Number 60 / POJK.04 / 2017 concerning the Issuance and Requirements for Green Bonds, the definition of green bonds is stated:

"Debt securities whose issuance proceeds are used to finance or refinance part or all of environmental business activities."

Furthermore, in the Article, referred to as environmentally sound activities are business activities and/or other activities aimed at protecting, improving, and/or enhancing the quality or function of the environment.

\subsection{Green Bond Principle}

Green Bonds have principles called The Green Bond Principle as guidelines for the standardization of issuance and implementation issued by the International Capital Market Association. The Green Bond Principle (ICMA, 2018) has four main principle components, namely as follows:

\subsubsection{Use of Proceeds}

The cornerstone of a green bond is the utilization of the proceeds of the bond for green projects, which should be appropriately described in the legal documentation for the security. All designed green projects should provide clear environmental benefits, which will be assessed and, where feasible, quantified by the issuer.

Eligible Green Project must fall into at least one of the following sectors:

\begin{tabular}{|c|c|}
\hline Eligible Sectors & Further Detail of Eligible Green Projects \\
\hline $\begin{array}{l}\text { Renewable } \\
\text { Energy }\end{array}$ & $\begin{array}{l}\text { - Generation and transmission of energy from } \\
\text { renewable energy sources: include offshore and } \\
\text { onshore wind, solar, tidal, hydropower, biomas, } \\
\text { and geothermal } \\
\text { - Research and development of products or } \\
\text { technology for renewable energy generation, } \\
\text { including turbines and solar panels }\end{array}$ \\
\hline Energy & - Improvement \\
\hline
\end{tabular}




\begin{tabular}{|c|c|}
\hline Efficiency & $\begin{array}{l}\text { infrastructure, which results in energy consumption } \\
\text { of at least } 10 \% \text { below the average national energy } \\
\text { consumption of an equivalent infrastructure } \\
\text { - Research and development of products or } \\
\text { technology and their implementation that reduces } \\
\text { the energy consumption of underlying assets, } \\
\text { technology, products or system (s); including LED } \\
\text { lights, improved chillers, improved lightning } \\
\text { technology, and reduced power usage in } \\
\text { manufacturing operations }\end{array}$ \\
\hline \begin{tabular}{lr}
\multicolumn{2}{c}{ Resilience to } \\
Climate & Change for \\
Highly & Vulnerable \\
Areas and & Sectors / \\
Disasters & Risk \\
Reduction &
\end{tabular} & $\begin{array}{l}\text { - The research leading to technology innovation with } \\
\text { sustainability benefits } \\
\text { - Food security } \\
\text { - Flood mitigation } \\
\text { - Drought management } \\
\text { - Public health management }\end{array}$ \\
\hline $\begin{array}{l}\text { Sustainable } \\
\text { Transport }\end{array}$ & $\begin{array}{l}\text { - Developing clean transportation systems } \\
\text { - Transportation network upgrade to higher climate- } \\
\text { resilient design standards }\end{array}$ \\
\hline $\begin{array}{l}\text { Waste to Energy } \\
\text { and Waste Management }\end{array}$ & $\begin{array}{l}\text { - Improving waste management } \\
\text { - Transforming waste to renewable energy sources } \\
\text { - } \quad \text { Rehabilitation of landfill areas } \\
\end{array}$ \\
\hline $\begin{array}{l}\text { Sustainable } \\
\text { Management of Natural } \\
\text { Resources }\end{array}$ & $\begin{array}{l}\text { - Sustainable management of natural resources which } \\
\text { substantially avoids or reduces carbon loss / } \\
\text { increase carbon sequestration (through the planting } \\
\text { of new forest areas and/or replanting of degraded } \\
\text { areas, the use of drought/flood/temperature resistant } \\
\text { species) } \\
\text { - Habitat and biodiversity conservation (through } \\
\text { sustainable management of land-use change, } \\
\text { sustainable management } \\
\text { agriculture/fisheries/forestry, protection of coastal } \\
\text { and marine environments, pets management }\end{array}$ \\
\hline Green Tourism & $\begin{array}{l}\text { - Developing new tourism areas in line with Green } \\
\text { Tourism Principles } \\
\text { - Optimization of supporting infrastructure to support } \\
\text { sustainable tourism (include water treatment, energy } \\
\text { efficiency) } \\
\text { - Developing tourism resiliency against climate } \\
\text { change risk }\end{array}$ \\
\hline Green Buildings & $\begin{array}{l}\text { - Developing green buildings in line with Greenship } \\
\text { developed by Green Building Council Indonesia } \\
\text { ("GBC Indonesia"), which contain six categories: } \\
\text { - Appropriate Site Development } \\
\text { - Energy Efficiency and Conservation } \\
\text { - } \text { Water conservation } \\
\text { - } \text { Material \& resources cycle } \\
\text { - Air quality \& leisure air (water indoor health \& }\end{array}$ \\
\hline
\end{tabular}




\begin{tabular}{|c|l|}
\hline & \multicolumn{1}{|c|}{ comfort) } \\
& $-\quad$ Buiding \& environment management \\
\hline Sustainable & $\bullet \begin{array}{l}\text { Developing sustainable agriculture management and } \\
\text { methods, such as organic farming fewer pesticides, } \\
\text { Agriculture }\end{array}$ \\
& $\begin{array}{l}\text { Research and Development on resilient climate } \\
\text { seeds and energy-efficient agriculture }\end{array}$ \\
& $-\quad$ Subsidy mechanism for agriculture insurance \\
\hline
\end{tabular}

(Source: The Republic of Indonesia Green Bond and Green Sukuk Framework)

\subsubsection{Process for Project Evaluation and Selection}

The issuer of a green bond should clearly communicate to investors: (i) the environmental sustainability objectives; (ii) the process by which the issuer determines how the projects fit within the eligible green projects categories identified above; (iii) the related eligibility criteria, including, if the applicable exclusion criteria or any other process applied to identified and manage potentially material environmental and social risks associated with the projects.

\subsubsection{Management of Proceed}

The net proceeds of the green bond or an amount equal to these net proceeds should be credited to sub-account, moved to a sub-portfolio or otherwise tracked by the issuer in an appropriate manner, and attested by the issuer in a formal internal process linked to the issuer's lending and investment operations for green projects. So long as the green bond is outstanding, the balance of the tracked net proceeds should be periodically adjusted to match allocations to eligible green projects made during that period. The issuer should make known to the investors the intended types of temporary placement for the balance of unallocated net proceeds.

\subsubsection{Reporting}

Issuers should make and keep readily available up to date information on the use of proceeds to be renewed annually until full allocation and on a timely basis in case of material developments. The annual report should include a list of the projects to which green bond proceeds have been allocated, as well as a brief description of the projects and the amounts allocated and their expected impact.

\subsection{Type of Green Bonds}

In several countries, the green bond market has grown bigger than in Indonesia. Green bonds have several types, as in the table below:

\begin{tabular}{|c|c|c|c|}
\hline \multirow[t]{2}{*}{ Type } & Proceeds & Debt & Example \\
\hline & $\begin{array}{l}\text { Raised by Bond } \\
\text { Sale Are }\end{array}$ & Resource & \\
\hline $\begin{array}{l}\text { "Use of Proceeds" } \\
\text { Bond }\end{array}$ & $\begin{array}{ll}\text { Earmarked for } \\
\text { green projects }\end{array}$ & $\begin{array}{l}\text { A resource to the } \\
\text { issuer: same credit } \\
\text { rating applies as }\end{array}$ & $\begin{array}{l}\text { EIB "ClimateAwareness } \\
\text { Bond" (backed by EIB); } \\
\text { Barclays Green Bond }\end{array}$ \\
\hline
\end{tabular}




\begin{tabular}{|c|c|c|c|}
\hline & & $\begin{array}{ll}\text { issuer's } & \text { other } \\
\text { bonds } & \\
\end{array}$ & \\
\hline $\begin{array}{l}\text { "Use of Proceeds" } \\
\text { Revenue bonds or } \\
\text { ABS }\end{array}$ & $\begin{array}{l}\text { Earmarked for or } \\
\text { refinances green } \\
\text { projects }\end{array}$ & $\begin{array}{l}\text { Revenue streams } \\
\text { for the issuer } \\
\text { through fees. } \\
\begin{array}{l}\text { Taxes etc. are } \\
\text { collateral for the } \\
\text { debt }\end{array}\end{array}$ & $\begin{array}{l}\text { Hawaii States (backed by a } \\
\text { fee on electricity bills of } \\
\text { the state utilities) }\end{array}$ \\
\hline Project Bond & $\begin{array}{l}\text { Ring-fenced for } \\
\text { the } \quad \text { specific } \\
\text { underlying green } \\
\text { project (s) }\end{array}$ & $\begin{array}{l}\text { The resource is } \\
\text { only to the } \\
\text { project's assets and } \\
\text { balance sheet }\end{array}$ & $\begin{array}{llr}\text { Invenergy } & \text { Wind } & \text { Farm } \\
\text { (backed } & \text { by Invenergy } \\
\text { Campo } & \text { Palomas } & \text { wind } \\
\text { farm) } & & \\
\end{array}$ \\
\hline $\begin{array}{l}\text { Securitization } \\
\text { (ABS) Bond }\end{array}$ & $\begin{array}{lr}\text { Refinance } & \\
\text { portfolios of green } \\
\text { projects } & \text { or } \\
\text { proceeds } & \text { are } \\
\text { earmarked } & \text { for } \\
\text { green projects } & \end{array}$ & $\begin{array}{l}\text { A resource is a } \\
\text { group of projects } \\
\text { that have been } \\
\text { grouped together } \\
\text { (e.g., solar leases } \\
\text { or green } \\
\text { mortgages) }\end{array}$ & $\begin{array}{l}\text { Tesla Energy (backed by } \\
\text { residential solar leases); } \\
\text { Obvion (backed by green } \\
\text { mortgages) }\end{array}$ \\
\hline Covered Bond & $\begin{array}{lr}\text { Earmarked } & \text { for } \\
\text { eligible projects } \\
\text { included } \\
\text { eligible assets }\end{array}$ & $\begin{array}{l}\text { A resource to the } \\
\text { issuer and, if the } \\
\text { issuer is unable to } \\
\text { repay the bond, to } \\
\text { the covered pool }\end{array}$ & 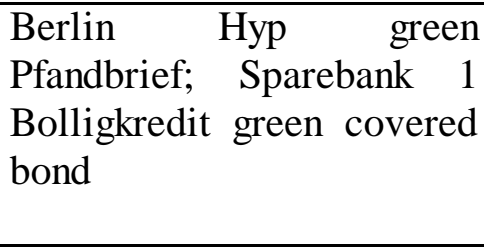 \\
\hline Loan & $\begin{array}{l}\text { Earmarked for } \\
\text { eligible projects or } \\
\text { secured on eligible } \\
\text { assets }\end{array}$ & $\begin{array}{l}\text { Full recourse to } \\
\text { the borrower (s) in } \\
\text { the case of } \\
\text { unsecured loans. } \\
\text { Recourse to the } \\
\text { collateral in the } \\
\text { case of secured } \\
\text { loans, but may } \\
\text { also feature } \\
\text { limited recourse to } \\
\text { the borrower }(\mathrm{s})\end{array}$ & $\begin{array}{ll}\text { MEP Werke, } & \text { Ivanhoe } \\
\text { Cambridge and Natixis } \\
\text { Assurances (DUO), OVG }\end{array}$ \\
\hline $\begin{array}{l}\text { Other } \\
\text { Instrument }\end{array}$ & $\begin{array}{l}\text { Earmarked for } \\
\text { eligible projects }\end{array}$ & & $\begin{array}{lcr}\text { Convertible } & \text { Bonds or } \\
\text { Notes, } & \text { Schudschein, } \\
\text { Commercial paper, Sukuk, } \\
\text { Debentures }\end{array}$ \\
\hline
\end{tabular}

\subsection{Green Bonds Scheme}

Basically, the green bonds issuance scheme is the same as the issuance of bonds in general as stipulated in the laws and regulations in the capital market. The following is an explanation of the mechanism for issuing bonds by corporations.

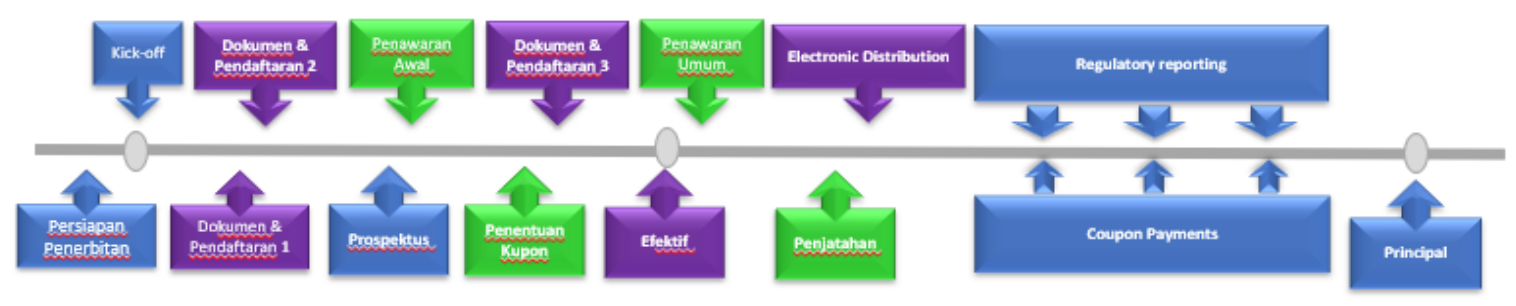




\subsubsection{Publishing Preparation}

In this stage, the corporation carries out the process of procuring the services of Bond Issuer Supporting Services, consisting of a) Capital Market Supporting Institutions / Professionals (parties), trustees, Underwriters, Securities Rating Agencies, Notaries, Public Accountants, Consultants Law.

\subsubsection{Kick-Off Meeting}

After the procurement process, a lead underwriter is determined who will coordinate the entire issuance and transaction process, including with the issuer, supporting professions, and regulators. The lead Underwriter compiles a time table, then submits it to the bond issuance team for review to be mutually agreed upon.

\subsubsection{Registration Stage 1}

The Company submits a registration statement addressed to the Capital Market Supervisory Executive with the Financial Services Authority registration documents required for this registration. The Financial Services Authority has the right to request additional information in connection with the submission of registration for bond issuance. Particularly for the issuance of green bonds, the registration document must also be accompanied by a commitment letter from the issuer to use the proceeds from the issuance of green bonds on the environmental strength to be financed. Then there must be an opinion from the Environmental Expert that the strength of the business or other activities underlying the issuance of green bonds is beneficial for the environment along with evidence of competence from the Environmental Expert.

\subsubsection{Registration Stage 2}

The next stage is the submission of changes / additional registration information 2 to the OJK and a brief Prospectus Publication Permit (verbal pre-effective statement) from the OJK.

\subsubsection{Announcement of Concise Prospectus}

A brief prospectus that has been submitted to the Financial Services Authority is published in the mass media, at least 1 (one) media that has national circulation. However, for this next stage of publication, it is sufficient for publication to be made on the website of the Financial Services Authority and the website of the Company. Evidence of publication of the brief prospectus is submitted to the Financial Services Authority again. Public exposes / Investor Gathering (if needed), which is intended to make the investor public aware of the planned public offering of bonds. For the prospectus in issuing green bonds, there must be a description of environmentally friendly business activities financed by the proceeds from the issuance of green bonds.

\subsubsection{Coupon Determination and Final Structure}

Initial bid to see investors' attention and the estimated bid price for securities, using the initial prospectus or interest sheet to capture the interest of potential investors. Through 
the interest sheet, potential investors fill in the value of the bonds to be ordered and the coupons requested.

\subsubsection{Effective Statement}

The Financial Services Authority provides an effective statement after the issuer meets the requirements and procedures for the Registration Statement completely. There are no more changes or additions based on the time span that has been given.

\subsubsection{Public Offering}

After obtaining the effective statement from OJK, then next, provide a final prospectus for potential investors and make revisions or additions to the Abridged Prospectus published in the mass media, such as the previous Abridged Prospectus announcement stage.

\subsubsection{Payment}

The payment process is carried out according to the Investor's statement of interest. After that, the Investor makes a payment for the purchase of Bonds through an underwriter to an account that is determined by the Underwriter to make payments to the Custodian Bank.

\subsubsection{Regulatory Reporting}

We are submitting reports on the results of the Public Offering and Realization of Use of Funds (LPRD) to the Financial Services Authority and the Trustee on a semi-annual basis.

\subsection{Benefits of Green Bonds Issuance}

The issuance of green bonds can certainly act as an additional alternative source of financing related to projects that care about the environment in a broad sense. The following explains some of the benefits of issuing green bonds (Thomas Kenny 2019):

a. First, there is investor diversification, where green bonds provide more access to investors who are concerned with environmental issues and general investors who have broad insight in making investment decisions.

b. Second, green bonds can improve the issuer's reputation. This is because the issuer is considered to have shown a commitment to caring for sustainable development.

c. Companies that issue green bonds will certainly increase their nature management and conservation activities so that they can increase employment for the community and participate in helping the community's economic growth.

Apart from the qualitative benefits above, the issuance of green bonds also has quantitative benefits, where green bonds trigger a positive market response, are able to improve financial and environmental performance, and attract long-term investors (Caroline Flammer, 2018). On a domestic scale, the domestic government also participates in providing benefits for green bond issuers, namely providing incentives in the form of a $50 \%$ (fifty percent) cut of the cost of listing green bonds on the stock exchange. This is stated in the Decree of the Board of Directors of PT Bursa Efek Indonesia number Kep-0038 / BEI / 052020 concerning Amendment to the IB Regulation concerning Registration of Debt Securities. 


\section{Method of Analysis}

In Indonesia, the issuance of Green Bonds has not developed much, although, in many other countries, it has become an instrument that has been pushed by the government. According to data presented by PT Penilai Harga Efek Indonesia (2020), only one issuer has issued a Green Bond in Indonesia, namely PT Sarana Multi Infrastruktur (Persero), with the following issuance details:

Figure 2. List of Corporate Bonds / Sukuk 2019-2020 (2020)

\begin{tabular}{|c|c|c|c|c|c|c|c|c|}
\hline 7. & $\begin{array}{l}\text { GNSMII01ACN1 } \\
\text { IDA0000926A8 }\end{array}$ & $\begin{array}{l}\text { Green Bond Berkelanjutan I } \\
\text { Sarana Multi Infrastruktur } \\
\text { Tahap I Tahun } 2018 \text { Seri A }\end{array}$ & $\begin{array}{l}\text { 9-Jul-18 } \\
251,500\end{array}$ & $\begin{array}{l}\text { 6-Jul-21 } \\
3 \text { years }\end{array}$ & $\begin{array}{l}\text { idAAA } \\
\text { Stable }\end{array}$ & $7.55 \%$ & $\begin{array}{l}\text { Bank Mandiri } \\
\text { (Persero) Tbk }\end{array}$ & $\begin{array}{c}\text { CGS-CIMB Sekuritas Indonesia, } \\
\text { Danareksa Sekuritas, Indo } \\
\text { Premier Sekuritas }\end{array}$ \\
\hline 8. & $\begin{array}{l}\text { GNSMII01BCN1 } \\
\text { IDA0000926B6 }\end{array}$ & $\begin{array}{l}\text { Green Bond Berkelanjutan I } \\
\text { Sarana Multi Infrastruktur } \\
\text { Tahap I Tahun } 2018 \text { Seri B }\end{array}$ & $\begin{array}{l}\text { 9-Jul-18 } \\
248,500\end{array}$ & $\begin{array}{l}6 \text {-Jul-23 } \\
5 \text { years }\end{array}$ & $\begin{array}{l}\text { idAAA } \\
\text { Stable }\end{array}$ & $7.80 \%$ & $\begin{array}{l}\text { Bank Mandiri } \\
\text { (Persero) Tbk }\end{array}$ & $\begin{array}{c}\text { CGS-CIMB Sekuritas Indonesia, } \\
\text { Danareksa Sekuritas, Indo } \\
\text { Premier Sekuritas }\end{array}$ \\
\hline
\end{tabular}

From the table above, the total issuance of Green Bonds that have occurred in Indonesia to date is only IDR 500,000,000,000. Because the sole actor is the issuer of the Green Bond, the analytical methods used by the author are the Vertical Common Size Analysis and Horizontal Common Size Analyzes.

\subsection{Vertical Common Size Analysis}

Vertical Common Size Analysis used to provide comparisons between Green Bonds and other bonds issued by PT Sarana Multigriya Financial (Persero) 


\begin{tabular}{|c|c|c|c|c|c|c|c|c|}
\hline 105. & SMII & PT Sarana Multi Infrastru & ktur (Perser & ) Tbk. & & & & Finance | 82. Financial Institution \\
\hline 1. & $\begin{array}{l}\text { SMII01ACN1 } \\
\text { IDA0000775A9 }\end{array}$ & $\begin{array}{l}\text { Obligasi Berkelanjutan I } \\
\text { Sarana Multi Infrastruktur } \\
\text { Tahap I Tahun } 2016 \text { Seri A }\end{array}$ & $\begin{array}{c}21-\text { Nov-16 } \\
2,298,000\end{array}$ & $\begin{array}{c}\text { 18-Nov-19 } \\
3 \text { years }\end{array}$ & $\begin{array}{l}\text { idAAA } \\
\text { Stable }\end{array}$ & $7.85 \%$ & $\begin{array}{l}\text { Bank Mandiri } \\
\text { (Persero) Tbk }\end{array}$ & $\begin{array}{l}\text { BCA Sekuritas, CIMB } \\
\text { Securities Indonesia, } \\
\text { Danareksa Sekuritas }\end{array}$ \\
\hline 2. & $\begin{array}{l}\text { SMII01BCN1 } \\
\text { IDA0000775B7 }\end{array}$ & $\begin{array}{l}\text { Obligasi Berkelanjutan I } \\
\text { Sarana Multi Infrastruktur } \\
\text { Tahap I Tahun } 2016 \text { Seri B }\end{array}$ & $\begin{array}{c}21-\text { Nov-16 } \\
1,328,000\end{array}$ & $\begin{array}{c}18-\mathrm{Nov}-21 \\
5 \text { years }\end{array}$ & $\begin{array}{l}\text { idAAA } \\
\text { Stable }\end{array}$ & $8.20 \%$ & $\begin{array}{l}\text { Bank Mandiri } \\
\text { (Persero) Tbk }\end{array}$ & $\begin{array}{l}\text { BCA Sekuritas, CIMB } \\
\text { Securities Indonesia, } \\
\text { Danareksa Sekuritas }\end{array}$ \\
\hline 3. & $\begin{array}{l}\text { SMII01CCN1 } \\
\text { IDA00000775C5 }\end{array}$ & $\begin{array}{l}\text { Obligasi Berkelanjutan I } \\
\text { Sarana Multi Infrastruktur } \\
\text { Tahap I Tahun } 2016 \text { Seri C }\end{array}$ & $\begin{array}{c}21-\text { Nov-16 } \\
700,000\end{array}$ & $\begin{array}{c}18-\text { Nov- } 26 \\
10 \text { years }\end{array}$ & $\begin{array}{l}\text { idAAA } \\
\text { Stable }\end{array}$ & $8.65 \%$ & $\begin{array}{l}\text { Bank Mandiri } \\
\text { (Persero) Tbk }\end{array}$ & $\begin{array}{l}\text { BCA Sekuritas, CIMB } \\
\text { Securities Indonesia, } \\
\text { Danareksa Sekuritas }\end{array}$ \\
\hline 4. & $\begin{array}{l}\text { SMII01DCN1 } \\
\text { IDA0000775D3 }\end{array}$ & $\begin{array}{l}\text { Obligasi Berkelanjutan I } \\
\text { Sarana Multi Infrastruktur } \\
\text { Tahap I Tahun } 2016 \text { Seri D }\end{array}$ & $\begin{array}{c}21-\text { Nov- } 16 \\
674,000\end{array}$ & $\begin{array}{c}18-N o v-31 \\
15 \text { years }\end{array}$ & $\begin{array}{l}\text { idAAA } \\
\text { Stable }\end{array}$ & $8.90 \%$ & $\begin{array}{l}\text { Bank Mandiri } \\
\text { (Persero) Tbk }\end{array}$ & $\begin{array}{l}\text { BCA Sekuritas, CIMB } \\
\text { Securities Indonesia, } \\
\text { Danareksa Sekuritas }\end{array}$ \\
\hline 5. & $\begin{array}{l}\text { SMII01BCN2 } \\
\text { IDA0000859B9 }\end{array}$ & $\begin{array}{l}\text { Obligasi Berkelanjutan I } \\
\text { Sarana Multi Infrastruktur } \\
\text { Tahap II Tahun } 2017 \text { Seri B }\end{array}$ & $\begin{array}{c}16-\text { Nov- } 17 \\
4,455,000\end{array}$ & $\begin{array}{c}15-\mathrm{Nov}-20 \\
3 \text { years }\end{array}$ & $\begin{array}{l}\text { idAAA } \\
\text { Stable }\end{array}$ & $7.40 \%$ & $\begin{array}{l}\text { Bank Mandiri } \\
\text { (Persero) Tbk }\end{array}$ & $\begin{array}{l}\text { BCA Sekuritas, CIMB } \\
\text { Securities Indonesia, } \\
\text { Danareksa Sekuritas }\end{array}$ \\
\hline 6. & $\begin{array}{l}\text { SMII01CCN2 } \\
\text { IDA0000859C7 }\end{array}$ & $\begin{array}{l}\text { Obligasi Berkelanjutan I } \\
\text { Sarana Multi Infrastruktur } \\
\text { Tahap II Tahun } 2017 \text { Seri C }\end{array}$ & $\begin{array}{c}16-\text { Nov-17 } \\
1,345,000\end{array}$ & $\begin{array}{c}15-\mathrm{Nov}-22 \\
5 \text { years }\end{array}$ & $\begin{array}{l}\text { idAAA } \\
\text { Stable }\end{array}$ & $7.60 \%$ & $\begin{array}{l}\text { Bank Mandiri } \\
\text { (Persero) Tbk }\end{array}$ & $\begin{array}{l}\text { BCA Sekuritas, CIMB } \\
\text { Securities Indonesia, } \\
\text { Danareksa Sekuritas }\end{array}$ \\
\hline 7. & $\begin{array}{l}\text { GNSMII01ACN1 } \\
\text { IDA0000926A8 }\end{array}$ & $\begin{array}{l}\text { Green Bond Berkelanjutan I } \\
\text { Sarana Multi Infrastruktur } \\
\text { Tahap I Tahun } 2018 \text { Seri A }\end{array}$ & $\begin{array}{l}\text { 9-Jul-18 } \\
251,500\end{array}$ & $\begin{array}{l}\text { 6-Jul-21 } \\
3 \text { years }\end{array}$ & $\begin{array}{l}\text { idAAA } \\
\text { Stable }\end{array}$ & $7.55 \%$ & $\begin{array}{l}\text { Bank Mandiri } \\
\text { (Persero) Tbk }\end{array}$ & $\begin{array}{l}\text { CGS-CIMB Sekuritas Indonesia, } \\
\text { Danareksa Sekuritas, Indo } \\
\text { Premier Sekuritas }\end{array}$ \\
\hline & $\begin{array}{l}\text { GNSMII01BCN1 } \\
\text { IDA0000926B6 }\end{array}$ & $\begin{array}{l}\text { Green Bond Berkelanjutan I } \\
\text { Sarana Multi Infrastruktur } \\
\text { Tahap I Tahun } 2018 \text { Seri B }\end{array}$ & $\begin{array}{l}\text { 9-Jul-18 } \\
248,500\end{array}$ & $\begin{array}{l}6-\text { Jul- } 23 \\
5 \text { years }\end{array}$ & $\begin{array}{l}\text { idAAA } \\
\text { Stable }\end{array}$ & $7.80 \%$ & $\begin{array}{l}\text { Bank Mandiri } \\
\text { (Persero) Tbk }\end{array}$ & $\begin{array}{l}\text { CGS-CIMB Sekuritas Indonesia, } \\
\text { Danareksa Sekuritas, Indo } \\
\text { Premier Sekuritas }\end{array}$ \\
\hline 9. & $\begin{array}{l}\text { SMSMII01ACN1 } \\
\text { IDJ0000110A0 }\end{array}$ & $\begin{array}{c}\text { Sukuk Mudharabah } \\
\text { Berkelanjutan I Sarana Multi } \\
\text { Infrastruktur Tahap I Tahun } \\
2018 \text { Seri A } \\
\end{array}$ & $\begin{array}{l}\text { 9-Jul-18 } \\
680,000\end{array}$ & $\begin{array}{l}\text { 6-Jul-21 } \\
3 \text { years }\end{array}$ & $\begin{array}{l}\text { idAAA(sy) } \\
\text { Stable }\end{array}$ & $7.50 \%$ & $\begin{array}{l}\text { Bank Mandiri } \\
\text { (Persero) Tbk }\end{array}$ & $\begin{array}{l}\text { CGS-CIMB Sekuritas Indonesia, } \\
\text { Danareksa Sekuritas, Indo } \\
\text { Premier Sekuritas }\end{array}$ \\
\hline 10. & $\begin{array}{c}\text { SMSMII01BCN1 } \\
\text { IDJ0000110B8 }\end{array}$ & $\begin{array}{c}\text { Sukuk Mudharabah } \\
\text { Berkelanjutan I Sarana Multi } \\
\text { Infrastruktur Tahap I Tahun } \\
2018 \text { Seri B } \\
\end{array}$ & $\begin{array}{l}\text { 9-Jul-18 } \\
320,000\end{array}$ & $\begin{array}{l}6 \text {-Jul- } 23 \\
5 \text { years }\end{array}$ & $\begin{array}{l}\text { idAAA(sy) } \\
\text { Stable }\end{array}$ & $7.75 \%$ & $\begin{array}{l}\text { Bank Mandiri } \\
\text { (Persero) Tbk }\end{array}$ & $\begin{array}{l}\text { CGS-CIMB Sekuritas Indonesia, } \\
\text { Danareksa Sekuritas, Indo } \\
\text { Premier Sekuritas }\end{array}$ \\
\hline 11. & $\begin{array}{l}\text { SMII01ACN3 } \\
\text { IDA0000947A4 }\end{array}$ & $\begin{array}{l}\text { Obligasi Berkelanjutan I } \\
\text { Sarana Multi Infrastruktur } \\
\text { Tahap III Tahun } 2018 \text { Seri A }\end{array}$ & $\begin{array}{l}\text { 5-Dec-18 } \\
846,000\end{array}$ & $\begin{array}{c}\text { 14-Dec-19 } \\
1 \text { years }\end{array}$ & $\begin{array}{l}\text { idAAA } \\
\text { Stable }\end{array}$ & $8.20 \%$ & $\begin{array}{l}\text { Bank Mandiri } \\
\text { (Persero) Tbk }\end{array}$ & $\begin{array}{c}\text { Bahana Sekuritas, CGS-CIMB } \\
\text { Sekuritas Indonesia, } \\
\text { Danareksa Sekuritas }\end{array}$ \\
\hline 12. & $\begin{array}{l}\text { SMII01BCN3 } \\
\text { IDA0000947B2 }\end{array}$ & $\begin{array}{l}\text { Obligasi Berkelanjutan I } \\
\text { Sarana Multi Infrastruktur } \\
\text { Tahap III Tahun } 2018 \text { Seri B }\end{array}$ & $\begin{array}{l}\text { 5-Dec-18 } \\
199,250\end{array}$ & $\begin{array}{l}\text { 4-Dec- } 21 \\
3 \text { years }\end{array}$ & $\begin{array}{l}\text { idAAA } \\
\text { Stable }\end{array}$ & $8.70 \%$ & $\begin{array}{l}\text { Bank Mandiri } \\
\text { (Persero) Tbk }\end{array}$ & $\begin{array}{c}\text { Bahana Sekuritas, CGS-CIMB } \\
\text { Sekuritas Indonesia, } \\
\text { Danareksa Sekuritas }\end{array}$ \\
\hline 13. & $\begin{array}{l}\text { SMSMII01ACN2 } \\
\text { IDJ0000127A4 }\end{array}$ & $\begin{array}{c}\text { Sukuk Mudharabah } \\
\text { Berkelanjutan I Sarana Multi } \\
\text { Infrastruktur Tahap II Tahun } \\
2019 \text { Seri A } \\
\end{array}$ & $\begin{array}{c}22-\text { Mar- } 19 \\
240,000\end{array}$ & $\begin{array}{c}\text { 31-Mar-20 } \\
1 \text { years }\end{array}$ & $\begin{array}{l}\text { idAAA(sy) } \\
\text { Stable }\end{array}$ & $7.70 \%$ & $\begin{array}{l}\text { Bank Mandiri } \\
\text { (Persero) Tbk }\end{array}$ & $\begin{array}{l}\text { CGS-CIMB Sekuritas Indonesia, } \\
\text { Danareksa Sekuritas, Indo } \\
\text { Premier Sekuritas }\end{array}$ \\
\hline 15. & $\begin{array}{l}\text { SMII02ACN1 } \\
\text { IDA0000989A6 }\end{array}$ & $\begin{array}{l}\text { Obligasi Berkelanjutan II } \\
\text { Sarana Multi Infrastruktur } \\
\text { Tahap I Tahun } 2019 \text { Seri A }\end{array}$ & $\begin{array}{c}\text { 26-Jun-19 } \\
224,000\end{array}$ & $\begin{array}{l}5-J u l-20 \\
1 \text { years }\end{array}$ & $\begin{array}{l}\text { idAAA } \\
\text { Stable }\end{array}$ & $7.50 \%$ & $\begin{array}{l}\text { Bank Mandiri } \\
\text { (Persero) Tbk }\end{array}$ & $\begin{array}{l}\text { CGS-CIMB Sekuritas Indonesia, } \\
\text { Danareksa Sekuritas, Indo } \\
\text { Premier Sekuritas }\end{array}$ \\
\hline 16. & $\begin{array}{l}\text { SMII02BCN1 } \\
\text { IDA0000989B4 }\end{array}$ & $\begin{array}{l}\text { Obligasi Berkelanjutan II } \\
\text { Sarana Multi Infrastruktur } \\
\text { Tahap I Tahun } 2019 \text { Seri B }\end{array}$ & $\begin{array}{l}\text { 26-Jun-19 } \\
1,224,000\end{array}$ & $\begin{array}{c}25 \text {-Jun- } 22 \\
3 \text { years }\end{array}$ & $\begin{array}{l}\text { idAAA } \\
\text { Stable }\end{array}$ & $8.50 \%$ & $\begin{array}{l}\text { Bank Mandiri } \\
\text { (Persero) Tbk }\end{array}$ & $\begin{array}{l}\text { CGS-CIMB Sekuritas Indonesia, } \\
\text { Danareksa Sekuritas, Indo } \\
\text { Premier Sekuritas }\end{array}$ \\
\hline 17. & $\begin{array}{l}\text { SMII02CCN1 } \\
\text { IDA0000989C2 }\end{array}$ & $\begin{array}{l}\text { Obligasi Berkelanjutan II } \\
\text { Sarana Multi Infrastruktur } \\
\text { Tahap I Tahun } 2019 \text { Seri C }\end{array}$ & $\begin{array}{l}26 \text {-Jun-19 } \\
1,552,000\end{array}$ & $\begin{array}{c}25 \text {-Jun- } 24 \\
5 \text { years }\end{array}$ & $\begin{array}{l}\text { idAAA } \\
\text { Stable }\end{array}$ & $8.75 \%$ & $\begin{array}{l}\text { Bank Mandiri } \\
\text { (Persero) Tbk }\end{array}$ & $\begin{array}{l}\text { CGS-CIMB Sekuritas Indonesia, } \\
\text { Danareksa Sekuritas, Indo } \\
\text { Premier Sekuritas }\end{array}$ \\
\hline 18. & $\begin{array}{c}\text { SMII01B } \\
\text { IDA0000635B3 }\end{array}$ & $\begin{array}{c}\text { Obligasi I Sarana Multi } \\
\text { Infrastruktur Tahun } 2014 \\
\text { Seri B }\end{array}$ & $\begin{array}{l}\text { 12-Jun-14 } \\
900,000\end{array}$ & $\begin{array}{c}11-J u n-19 \\
5 \text { years }\end{array}$ & $\begin{array}{l}\text { idAAA } \\
\text { Stable }\end{array}$ & $10.00 \%$ & $\begin{array}{l}\text { Bank Mandiri } \\
\text { (Persero) Tbk }\end{array}$ & $\begin{array}{l}\text { CIMB Securities Indonesia, } \\
\text { Danareksa Sekuritas, Indo } \\
\text { Premier Securities }\end{array}$ \\
\hline 19. & $\begin{array}{l}\text { SMII01ACN2 } \\
\text { IDA0000859A1 }\end{array}$ & $\begin{array}{l}\text { Obligasi Berkelanjutan I } \\
\text { Sarana Multi Infrastruktur } \\
\text { Tahap II Tahun } 2017 \text { Seri A }\end{array}$ & $\begin{array}{c}16-\text { Nov- } 17 \\
1,200,000\end{array}$ & $\begin{array}{c}25-\text { Nov- } 18 \\
1 \text { years }\end{array}$ & $\begin{array}{l}\text { idAAA } \\
\text { Stable }\end{array}$ & $6.15 \%$ & $\begin{array}{l}\text { Bank Mandiri } \\
\text { (Persero) Tbk }\end{array}$ & $\begin{array}{l}\text { BCA Sekuritas, CIMB } \\
\text { Securities Indonesia, } \\
\text { Danareksa Sekuritas }\end{array}$ \\
\hline
\end{tabular}

(Source: Indonesian Securities Pricing Appraiser)

Based on this data, the following analyzes were obtained:

1. The average coupon rate for all debt securities issued was $8.06 \%$. The average interest rate for all debt securities is $0.51 \%$ higher than the Coupon for Sustainable Green Bond Phase I Series A and $0.26 \%$ higher than the Coupon for Sustainable Green Bond Phase I Series B.

2. In 2018, PT Sarana Multigriya Infrastruktur (Persero) issued debt securities six times, with an average coupon rate of $7.92 \%$. It is $0.37 \%$ higher than the coupon for Sustainable Green Bond Phase I Series A and 0.12\% higher than the coupon for Sustainable Green Bond Phase I Series B. 


\subsection{Vertical Common Size Analysis}

Vertical Common Size Analysis is used to provide a comparison of the fair price value of Green Bonds issued by PT Sarana Multi Infrastruktur (Persero) from the issuance until the second quarter of 2019

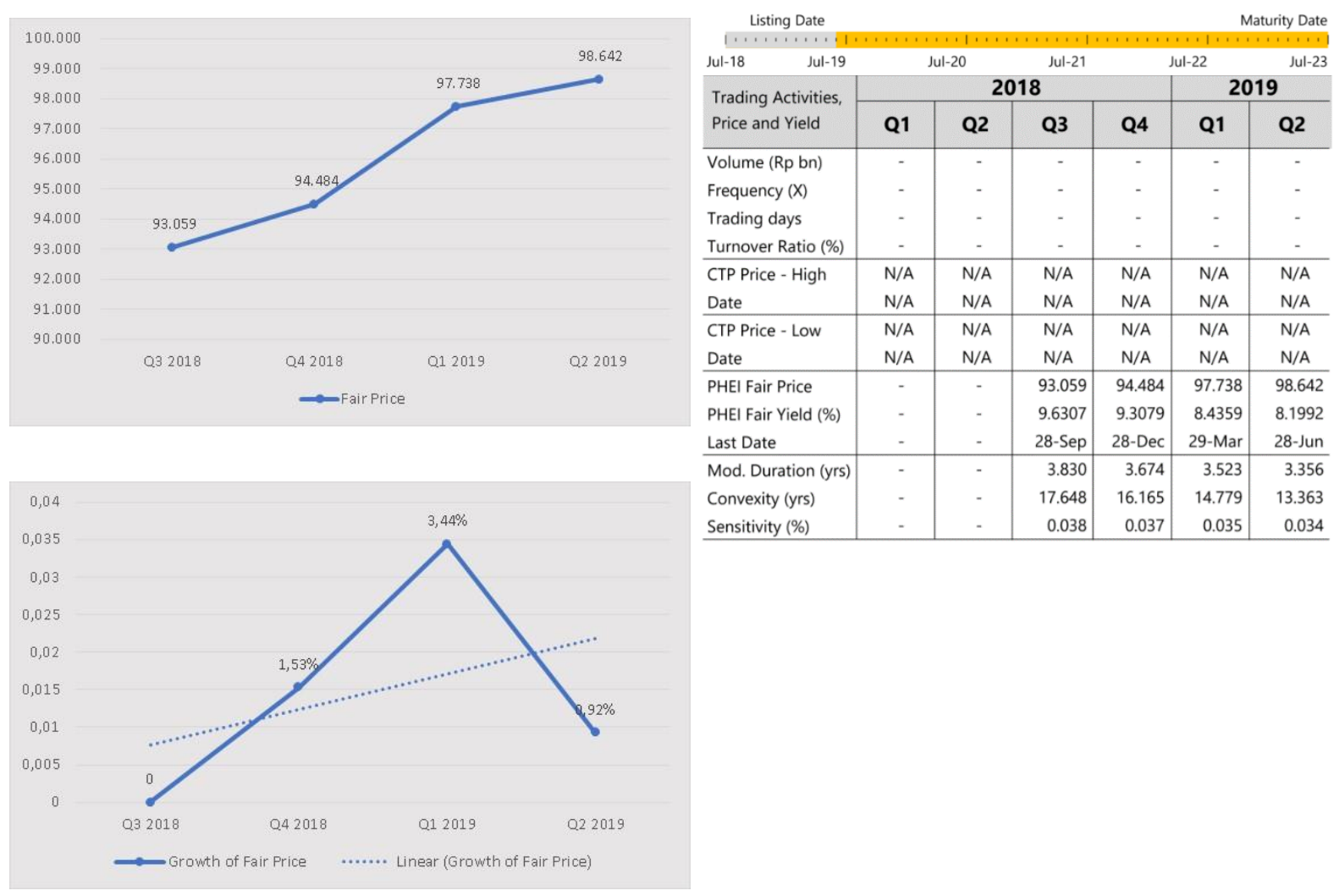

1. Fair price green Bonds issued by PT Sarana Multi Infrastruktur (Persero) are constantly increasing.

2. The fair price growth of Green Bonds issued by PT Sarana Multi Infrastruktur (Persero) has experienced an increasing trend since the issuance in the second quarter of 2018 until the second quarter of 2019.

\section{Conclusions and Recommendations}

\subsection{Conclusion}

a. There has been no growth in the issuance of Green Bonds in Indonesia since 2018 as the first Green Bond issuance by PT Sarana Multi Infrastruktur (Persero).

b. Fair price from Green Bonds in Indonesia issued by PT Sarana Multi Infrastruktur (Persero) is constantly increasing.

c. The coupon rate offered by Green Bond is below the average coupon for all debt securities issued by PT Sarana Multi Infrastruktur. This shows that the level of risk contained in the issuance of Green Bonds is smaller than the risk contained in ordinary debt securities (bonds). 
d. Green bonds are a fairly safe instrument for investors.

\subsection{Recommendation}

a. Companies that operate in the area of peatland distribution make peatland management integrated into the Company's business operations.

b. Companies around peatlands issue green bonds to increase their role in peatland management.

c. Intensive socialization from the government on the importance of the role of companies in issuing green bonds, as well as encouragement from the government in the form of incentives for each issuer. 


\section{BIBLIOGRAPHY}

\section{Book}

Central Bureau of Statistics. 2018. Indonesian Palm Oil Statistics 2018. Sub-directorate of Plantation Crop Statistics. Jakarta.

Financial Services Authority. 2016. The Study Report on Green Bond Development in Indonesia." Sustainable Finance Development Team in the Capital Markets Sector. Jakarta.

PT. Indonesian Stock Price Assessors. 2020. Indonesia Bond Market Directory 2019 - 2020. Indonesian Securities Pricing Appraiser. Jakarta.

Wijaya, Kresna. 2019. "Green Bond." Center for Sustainable Finance and KnowledgeIndonesian Banking Development Institute

\section{Journal}

Anugraheni, Pradina. 2017. "Analysis of Indonesia Sovereign Green Bond and Green Sukuk Initiatives. Economic \& Financial Studies Vol 1 No.1. Accessed on 28 October 2020.http://fiskal.kemenkeu.go.id/ejournal

Chiang, Jhon. 2017. "Growing The US Green Bond Market". Volume 1: The Barriers and $\begin{array}{lllll}\text { Challenges. } & \text { Accesed } & \text { on } & 28 & \text { October }\end{array}$ http://www.tresurer.ca.gov/greenbonds/publications/reports/1/pdf

Sola, Hardi. 2005. "The Effect of Peat Land Use for Agricultural Land on Changes in the Rate of Nitrogen Mineralization Rate." Indonesian Journal of Agricultural Sciences Volume 7, No.2, 2005, Bengkulu: Faculty of Agriculture, Bengkulu University.

Sudrajat, Agus Sarwo Edy and Sri Subekti, 2019. "Peat Ecosystem Management as an Effort to Mitigate Climate Change in South Kalimantan Province". Planalogi Journal, Volume 16, No.2, October 2019. Semarang: Sultan Agung Islamic University.

\section{Thesis}

Lestari, Niken Ayu. 2019. "The Legal Protection for Green Bond Investors on The Risk of Greenwashing". Brawijaya University LL.B Thesis.

\section{Website}

Bogor Soil Research Institute. 2020. "Characteristics of Peatlands". Accessed on 2 November 2020.

http://balittanah.litbang.pertanian.go.id/ind/dokument/juknis/punjuk\%20gambut\%20te rdegradasi/03ai_k Characteristik.pdf.

Cilimate Bond Initiatives, 2020. "Explaining Green Bonds". Accessed on November 1. https://www.climatebonds.net/market/explaining-green-bonds.

Director General of Financing and Risk Management, Ministry of Finance of the Republic of Indonesia, 2020. The Republic of Indonesia Green Bond and Green Sukuk Framewrok. Accessed $31 \quad$ October 2020.https://www.djppr.kemenkeu.go.id/uploads/files/dmodata/in/6Publikasi/Offering \%20Circular/ROI\%20Green\%20Bond\%20and\%20Green\%20Sukuk\%20Framework.p df 
International Capital Market Association, 2018. "Green Bond Principles". Accessed on 31 October 2020.https://www.icmagroup.org/assets/documents/Regulatory/GreenBonds/Green-Bonds-Principles-June-2018-270520.pdf 